\title{
On the Construction of a Learning Party Organization in Colleges and Universities
}

\author{
Tao Wenjuan
}

\begin{abstract}
This paper describes the connotation and characteristics of a learning Party organization and aims to provide some countermeasures and suggestions on the construction of a learning Party organization in colleges and universities by analyzing the current obstacles to it.
\end{abstract}

Index Terms - Construction, a learning party, discussion.

\section{INTRODUCTION}

The fourth Plenary Session of the 17th CPC Central Committee deliberated and approved the Decision of the Central Committee of the Communist Party of China on Strengthening and Improving the Construction of the Party under the New Situation and called special attention to view the construction of the Marxist Learning Party as a major and urgent task. The construction of a learning Party in colleges and universities is of great importance, such as giving full play to the functions of higher education, further promoting the staff to emancipate their minds, to change the working styles, to enhance service awareness, and to improve execution ability and so on.

\section{THE CONNOTATION AND CHARACTERISTICS OF A LEARNING PARTY ORGANIZATION}

\section{A. The Connotation of a Learning Organization and a Learning Party Organization}

A learning organization is an organization that is not only able to skillfully create, acquire and transfer knowledge, but also to modify its own behaviors to adapt to new knowledge and insights.

The development model of a learning Party is created by drawing the concepts of learning organizations. A learning Party, which is fundamental to a Marxist political party committed to learning, views learning as the most distinctive feature and the overall requirement. Learning is a common responsibility of the Party and everyone should be committed to learning and combine the individual learning and organizational development together. It emphasizes more on the inquiry learning, innovative learning and practical learning to help the Party acquire the ability of self-promotion by "learning". It also pays more attention on the long progress of learning and attempts to systematize and mechanize learning process. The construction of a learning Party organization should take into account the attributes of

Manuscript received February 15, 2017; revised May 5, 2017.

Tao Wenjuan is with the Nan Jing Forestry University, Nan Jing, Jiang Su, China (e-mail: 48355973@qq.com). the learning organization and the Party organization, which means that it should not only reflect the features of a learning organization, but also the essential characteristics of the Party organization and it should follow the basic requirements of a learning organization and take its own advantages of Party Organization [1]. In this process of constructing a learning Party, we should make full use of the Party's organizational and political advantage formed during its long-term practice to view the learning from a high organizing principle level. In addition, we should rely on the strong organization and its system to promote learning as one self-conscious behavior, so as we can make the learning inside the party more scientific, systematic, standard and normal.

\section{B. The Characteristics of a Learning Party Organization}

\section{1) Learning-oriented}

Learning is the most distinctive feature of a learning Party organization, also its important attribute and behavior pattern. Being different from all past learning activities carried out by the Party, the construction of this learning Party organization is going to transform it from a "general learning Party" to a "learning-oriented Party". This new Party enjoys a clear shared wish, the strong atmosphere of learning, a clear image of learning, the learning concepts of this age, the harmonious group learning atmosphere, the continuous exploring spirit and abundant innovative achievements.

\section{2) Political}

Chinese Communist Party is a Marxist ruling party and is different from the general management organization. Being political is the fundamental attribute of CCP. By inheriting the fine tradition and basic experience of its own and drawing from the concepts of learning organizations and society, the $\mathrm{CCP}$ formed this learning Party organization to keep and develop its progressiveness,

\section{3) Armed with theory}

Scientific theory is the most important element of the Marxist party. As Lenin said, the party without scientific theory "will lose the right to live and is doomed to suffer political bankruptcy". Being armed with scientific theory is the essential feature of the learning Party organization, and is also the essential difference between the learning-oriented and the general learning organization.

\section{4) Open}

A learning Party organization is an open organization, paying attention to self reflection and criticism, so that it can discover its own deficiencies and problems in time and give full play to the advantage of knowledge sharing and interaction and mutual assistance among the members. Being good at capturing the outside information, the Party can 
respond to the outside world changes in time and adjust its development strategies. Last but not least, the party can actively use the favorable conditions and useful experience outside the organization to achieve the "open development" [2].

\section{5) Innovative}

The learning Party is a growth organization, with innovative spirit as its essential attributes. Senge said: "If I had one word to describe the learning organization, it's innovation; if two words, it's continuous innovation." Innovation can effectively convert the learning behaviors of the organization and its members into the organization's innovative capacity, so as to promote the comprehensive development of the members and the continuous revolution and sustainable development of the organization.

\section{6) Democratic and efficient}

A learning Party organization is of flat, networked and flexible structure with an innovative team, a shared wish and the flexible management. Its value corresponds to the characteristics of democracy and efficiency.

\section{7) Practical}

It is known that the purpose of learning is to apply. The learning Party organization is a practical organization for several reasons: it pays abundant attention to integrating theory with practice, learning for practical use, solving practical problems and learning useful knowledge.

\section{OBSTACLES TO THE CONSTRUCTION OF A LEARNING PARTY ORGANIZATION IN COLLEGES AND UNIVERSITIES}

\section{A. Obstacles to Learning}

Some party members haven't fully realized the importance and necessity of constructing a learning Party organization. They always regard learning as a soft task and an additional burden assigned by the superiors. Those members take the theory as a surface packaging and lack due initiative, willingness and urgency, so they always view learning as an emergency or perfunctory measure. Other Party cadres have more continuous work experience, so they think that they can solve new problems with their old experience and they work with their old experience and practices. Some of them have a tendency of pragmatism. They learn what they need and what has close links to their work because of their particular stress on further study of business knowledge.

\section{B. Obstacles of Insufficient Attention}

A survey shows that most of the colleges and universities, in the construction process of a learning Party organization, are lacking in enough knowledge about it, which, in the specific promoting process, will inevitably lead to insufficient attention on it. The construction of Marxist learning Party organization hasn't been regarded as the initial political task and the working focus by some basic-level Party branch heads. Other Party branch heads think too many political learning activities will interfere in the normal teaching and scientific research activities. In specific practice, they just make written or oral announcements of the spirit of the important documents of the Party and the unified arrangements by college Party Committee instead of carrying out in-depth study and discussion. Few leading cadres, influenced by negative thoughts and social atmosphere like utilitarian, tend to ignore and neglect such learning, be keen on social activities, pursue personal enjoyment, be busy with looking for getting advances through the back door, sap their spirits by seeking pleasures and have no interest in learning. These problems should be paid much attention to and carefully dealt with.

\section{Obstacles of Insufficient Learning Motivation}

Although the Learning assessment mechanism of Party organization, in terms of forms, carriers and methods of innovative learning, has kept pace with the times, for the busy administration department, problems concerning learning motivation in the construction process of a learning basic-level Party organization haven't been well solved. First, in the assessment, the lack of combination of learning and cadre selection and appointment, assessment of professional titles and the students' performance, leads to the insufficient learning motivation of Party cadre in the learning process. Second, unscientific learning methods and contents are also the cause of the lack of learning motivation. Third, the common vision established by the school and departments haven't enjoyed popular support.

\section{Obstacles of Obsolete Learning Methods}

Learning activities organized by Party branches are inflexible and monotonous without strong pertinence. They are only satisfied with political preaching, short of inheritance and innovation, education on systematic Marxism theory and basic knowledge and the Party, in addition, short of communication exchange. Several individual branches even make such learning as a mere formality which focuses on reading and listening and adopts the instilling learning method through unilateral reading. Most of the reading contents are pure theory, drab and lack of readability so that people have no interest in learning and feel tired about it.

\section{E. Obstacles in the Learning System}

In the practice of constructing a learning Party organization, the System is a very weak link, which often leads to a result difficult to implement and difficult be make an effect. For example, in terms of learning input, there is no protection and no condition for systematic learning. As to learning supervision, there is no monitoring assessment for learning and the training just focus on the momentum rather than the substantial results. In the perspective of incentive mechanism, learning enthusiasm of the Party members hasn't been stimulated effectively. In the aspect of cadre selection, promotion of professional titles, there is no science-based selection and evaluation mechanism. Some members think that construction of Party branch means making a wholesome organization and implementing all the systems. Although some learning systems have been established, there are more principle demands than operational methods which make it difficult to carry on. Some learning systems, established just to cope with the assessment by higher superiors, seem to be a decoration without serious implementation. The unsound and imperfect learning system has become an important obstacle for the construction of a learning oriented Party organization. 


\section{F. Obstacles of Work and Learning Integration}

Marxist style of study, which combines theory with practice, is what a learning Party organization has to promote. By focusing on the work of their own department in their own region, Party members have to research on new situations and new problems, and through learning, they can broaden their horizons, open up their minds, and advance with the pace of the times, make new achievements in resolving the contradictions and problems concerning development. Individual departments focus on the study of political theory and ideological education instead of the study of knowledge management and modern scientific knowledge. Some Party members are forced to cope with the learning tasks without pertinence and creativity. Moreover, some Party members can't use what they have learned to guide their work.

\section{Measures and Suggestions for the Construction OF A LEARNING PARTY ORGANIZATION IN OUR COLLEGE}

\section{A. Strengthening the Study Subject, Clearing the Direction of Efforts}

The construction of learning oriented Party organizations should give full play to the role of Party organizations and Party members.

The first is to strengthen the party's leading role in the study of the center of the party committee, which is the key to build a learning party organization. Leading cadres, being the backbone of the cause of the party, should understand the strategic significance of the central group from the aspect of improving leadership and governance. In the face of profound changes in the domestic and international situation and the leadership of the group becoming complex unprecedentedly, we must strengthen learning, improve learning ability, and enhance the level of management and leadership.

The second is to strengthen the main position of learning in the Party branch. Party branch is the foundation and core of the party organization, concentrated by the Party members from the university students and teachers and varying grass-roots Party organizations. The branch should regard learning as a daily task, learn and absorb the theory of learning organization, so as to create a sound learning environment within the party, form a more benign interaction and self-renewal atmosphere. Thus Party branches will finally become a place for the party members to learn new knowledge, exchange ideas, hold together and advance.

The third is to strengthen the basic role of Party members themselves. Colleges and universities should guide all teaching staff and student party members firmly establish the concept of "to learn is to work and to work is to study" [3], and constantly improve the quality and level.

\section{B. Scientific and Reasonable Arrangement of Learning Contents}

Learning contents, which is the specific goal and task of the construction of a learning Party organization in college, is the basic factor for using the theoretical and innovative achievements to arm the Party cadres and member and to improve their ideological and theoretical attainments. The general office of the CPC Central Committee has explicitly stipulated the main learning contents in "Suggestions on promoting the construction of a learning Party organization" [4], which includes: the learning task is to learn the theoretical system of socialism with Chinese characteristics, to learn socialist core value system, to learn Party's regulations and national laws and regulations, to learn all aspects of knowledge necessary for modernization, on the basis of doing one's own job, to learn and understand the circumstance of our country, Party, province, society and college, to learn our college's development planning, working focus, key work, job characteristics and skill requirements according to the developing trend of higher education and the cause of forestry, to learn laws and regulations, developing trends, management, advanced educational thoughts and successful experience of higher education and to enhance knowledge and skill training so as to become the expert in one's own field.

In the construction process, the learning contents should be combined with one's own goal in life, such as Party member's physical quality, mental quality and harmonious interpersonal relationships, so the construction of a learning Party organization should involve: health knowledge, psychological knowledge, living skills, ways to deal with interpersonal and family relationships.

\section{Building a Flexible and Diverse Learning System}

A flexible and diverse learning system should be regarded as an important task in the construction of a learning Party organization.

\section{1) Strengthening the construction of the foundation.}

Colleges can take advantage of the web page of the Party committee, enriching the web learning program and speeding up the information updating, to provide "menu learning" [5] for Party members. Meanwhile, college should open online classes, Party schools, QQ groups and Fetion groups, make a continuous expansion of the number of books in the Party committee's library and speed up the flow of the books in order to provide a resource platform more efficient for the Party members.

\section{2) Exerting the advantage of carriers}

Colleges can expand the coverage of the central group; make innovations in the learning methods of discussion, question and research. Effective learning forms such as counseling reports, expert lectures, and job training and so on should be adopted. In addition, colleges should try to teaching through lively activities and gradually create a Party culture through various recreational and sports activities.

\section{3) Adhering to five combinations}

Colleges have to combining collective learning with self learning, compulsory knowledge with business knowledge; in-service learning with training; theory learning with specific research, learning achievements with working achievements.

\section{4) Adhering to learning through different levels}

Learning arrangement should be divided into 3 levels according to different titles:

D. Establishing a Long-Term Interactive Learning System 
It is not just a stage-based work but a long-term, strategic task and a huge systematic program to establish a learning Party organization. Strengthening the construction of a learning system is the basic work and demand of a learning Party organization. To carry out the standardized, long-term and normalized learning activities, colleges have to establish a target management system; attendance checking system, file management system, notification system, inspection system, assessment system, achievement exchange system and stable investment guarantee system.

\section{REFERENCES}

[1] Q. Wang, "On the construction of a learning Party organization in colleges and universities," Postgraduates thesis, Ocean University of China, May 2012.
[2] D. Xiao, "The basic experiences and innovation paths of the construction of a learning Party organization in colleges and universities," Party construction and ideological education in universities, vol. 8, p. 415, March 2012.

[3] G. Hu, "Difficulties and countermeasures in the construction of a learning Party organization in colleges and universities," Political Civilization, pp. 25-27, February 2012.

[4] X. He and J. Zhang, "Requirements analysis of a learning party organization in colleges and universities," Socialism, pp. 96-99, April 2012.

[5] J. Huang, "The practical path to the development of a learning Party organization in colleges and universities," Theoretical Front of Colleges and Universities, pp. 35-38, May 2012.

Tao Wenjuan was born in 1982. She is lecturer, Ph.D candidate. Her research direction is party building and ideological and political education of college students. 